\title{
Is Tattooing a Risk Factor for Hepatitis C Transmission?: An Updated Systematic Review and Meta-Analysis
}

\author{
Mahmoud Khodadost, ${ }^{1,2}$ Khadije Maajani, ${ }^{3}$ Masoumeh Arabsalmani, ${ }^{4}$ Nader Mahdavi, ${ }^{5}$ Reza Tabrizi, ${ }^{6}$ \\ and Seyed Moayed Alavian ${ }^{1,7, *}$ \\ ${ }^{1}$ Baqiyatallah Research Center for Gastroenterology and Liver Diseases (BRCGL), Baqiyatallah University of Medical Sciences, Tehran, IR Iran \\ ${ }^{2}$ Department of Epidemiology, Faculty of Health, Iran University of Medical Sciences, Tehran, IR Iran \\ ${ }^{3}$ Department of Epidemiology and Biostatistics, School of Public Health, Tehran University of Medical Sciences, Tehran, IR Iran \\ ${ }^{4}$ Department of Epidemiology and Biostatistics, School of Public Health, Zahedan University of Medical Sciences, Zahedan, IR Iran \\ ${ }^{5}$ Department of Epidemiology, Faculty of Health, Shahid Beheshti University of Medical Sciences, Tehran, IR Iran \\ ${ }^{6}$ Health Policy Research Center, Institute of Health, Student Research Committee, Shiraz University of Medical Sciences, Shiraz, Iran \\ ${ }^{7}$ Middle East Liver Diseases (MELD) Center, Tehran, IR Iran \\ "Corresponding author: Seyed Moayed Alavian, MD, Baqiyatallah Research Center for Gastroenterology and Liver Diseases (BRCGL), Baqiyatallah University of Medical Sciences, \\ Mollasadra, Tehran 17166, IR Iran. E-mail: alavian@thc.ir
}

Received 2017 May 30; Accepted 2017 July 22.

\begin{abstract}
Context: The aim of this systematic review was to assess the association of tattooing with the risk of hepatitis $\mathrm{C}$ infection. Evidence Acquisition: A systematic search was performed in Medline, Web of Science, Scopus, Google scholar, EMBASE, CINAHL, and PubMed up to May 2017. To analyze the data using random effect, odds ratio (OR) with $95 \%$ confidence interval (CI) was calculated for each study. We also determined publication bias and heterogeneity among the 162 extracted articles.

Results: We included 163 relevant studies out of the 2353 extracted studies into the meta-analysis process. When all studies were included in the meta-analysis, the association between tattooing and risk of hepatitis $\mathrm{C}$ transmission was strongly significant (pooled $\mathrm{OR}=2.79$, 95\% CI: 2.46 - 3.18). Subgroup analysis showed the strongest association between tattooing and the risk of hepatitis $\mathrm{C}$ among samples from blood donors groups ( $\mathrm{OR}=4.09,95 \% \mathrm{CI}: 2.80$ - 5.98).

Conclusions: This meta-analysis study revealed that tattooing is strongly associated with transmission of hepatitis $\mathrm{C}$ in all subgroups. Relevant education is recommended for young adults who are more likely to get tattoos as well as for prison inmates who have demonstrated high prevalence of hepatitis $C$ infection. In addition, it seems necessary to implement prevention programs and enforce guidelines for safer tattooing practices in tattoo parlors in order to prevent hepatitis $\mathrm{C}$ transmission.
\end{abstract}

Keywords: Tattooing, Hepatitis, Infection, Hepatitis C

\section{Context}

Tattooing has arisen from ancient times in many parts of the world $(1,2)$. In the United States, $24 \%$ of people aged 18 to 50 years have had at least one tattoo (3). According to a study conducted in Canada, $8 \%$ of high school students have had at least one tattoo on their bodies. In addition, $21 \%$ of people who do not have any tattoo on their bodies would like to have tattoos (4). In order to mark a tattoo, pigments are injected into the dermal layer of skin by puncturing the skin 80 to 150 times a minute. Therefore, it is obvious that tattooing tools are in contact with blood and body liquids and if the tattoo needles are reused for more than one person without performing proper sterilization process and hygiene techniques, the blood-borne diseases may be transmitted (5). Moreover, tattoo colors are usually kept in dirty dishes that are a good place for viral and bacterial pathogens and increase the risk of bloodborne diseases (5). Several studies reported a possible as- sociation between anti-HCV positivity and tattooing (6-12). The prevalence of HCV infection has been estimated about $3 \%$ in the world (13). There are approximately 170 million people with chronic hepatitis $\mathrm{C}$ virus (HCV) infection (14, 15). HCV infection is a major cause of liver cirrhosis, hepatocellular carcinoma (HCC), and end-stage liver disease (16, 17). Thus, HCV infection is a basic public health problem all around the world (18-20). Recently, drug injection is the most important risk factor for transmission of HCV infection. It is confirmed to be the cause of $60 \%$ of new $\mathrm{HCV}$ transmission cases every year due to sharing needle and drug use equipment $(21,22)$. Moreover, there is reliable evidence on the association between drug use by injection and hepatitis C; however, tattooing as a risk factor of HCV infection has remained a controversy $(12,23-26)$. Several articles have discussed tattooing as a rout of HCV transmission; however, other studies have not reported any significant association (23, 25-41). Early studies evaluating the relationship between the habit of tattooing and hepatitis

Copyright (c) 2017, Hepatitis Monthly. This is an open-access article distributed under the terms of the Creative Commons Attribution-NonCommercial 4.0 International License (http://creativecommons.org/licenses/by-nc/4.0/) which permits copy and redistribute the material just in noncommercial usages, provided the original work is properly cited. 
$C$ in the United States had recruited a small sample size (less than 100 in case-control studies and less than 2000 in cross-sectional studies). Hence, they were not able to report adjusted odds ratios (42). Moreover, studies that have shown a positive correlation between tattooing and hepatitis $C$ before 1992 were not able to control the effects of known risk factors for hepatitis $\mathrm{C}$ including blood transfusion and injecting drug use. History of transfusion before 1992 and IDUs history are the main risk factors for HCV infection and other risks are important as additive risks such as tattooing. Therefore, there are limitations in the interpretation of results (43). However, in a study in 2012, it was pointed out that the significance of these routs of transmission was clear in high-risk groups, but not clear enough in general population (42). One of these high-risk groups is prisoners, because prisoners have strong interest to tattooing. The overall prevalence of hepatitis $\mathrm{C}$ among prisoners is estimated to be $25.2 \%$ to $37.4 \%$ (44-48). About half of the prisoners may be unaware of their serological status and they probably do not have adequate knowledge on their health (49-53). Statistics show that it is a common habit to reuse tattoo needles and $45 \%$ of prisoners share the needles with others. The number of new cases of hepatitis $\mathrm{C}$ that occur due to tattooing is important for clinical and health care professionals. Nonetheless, there is a contrast between the results of epidemiological studies on the relationship between hepatitis C and tattooing. Consequently, the aim of the present study was to conduct a systematic review of these studies to determine the risk of hepatitis $\mathrm{C}$ among people who have tattoos.

\section{Methods}

\subsection{Search Strategy}

We searched several international databases including Medline, Web of Science, Scopus, Google scholar, SID, Magiran, Iranmedex, EMBASE, CINAHL, and PubMed from 1996 to May 2017. There was no limitation in our search strategy in terms of specific sub-population, languages, or time interval. The search included blood donors, prisoner, IDUs, Non-IDUs, homeless, and sex workers. The initial search strategy was generated using MeSH subject headings "hepatitis" and "tattoo" in MEDLINE. Related keywords and broad subject headings such as 'hepatitis' 'hepatitis C' and 'tattooing' were included later in the search strategy. In order to increase the sensitivity of the search and select a larger number of related studies, we screened the reference section of the retrieved studies and hand-searched the relevant review studies as well as books, abstracts, and key journals relating to hematology, gastroenterology, and hepatitis. EndNote X7, as citation manager software, was used to manage and screen papers from several online databases.

\subsection{Study Selection}

We included all observational studies (cohort, casecontrol, cross-sectional) that assessed the association between tattooing and risk of hepatitis $C$ infection in various study populations if they met the eligibility criteria. We used the following three eligibility criteria in the selection of relevant studies: (1) hepatitis $C$ as either primary or secondary outcome, 2) tattooing as either primary or secondary exposure and, 3) reports on relative risks or odds ratios and their $95 \%$ confidence intervals (95\% CI) or those providing sufficient data (e.g. cross tabulation of hepatitis $\mathrm{C}$ and tattooing from chi-square test or odds ratio and corresponding standard error (SE)) to compute these parameters. Two of the co-authors (KM and MA) independently reviewed the titles and abstracts of articles identified through our search strategy for decreasing the bias and excluded articles that did not meet the eligibility criteria. Articles included by either of the two reviewers were assessed for full text review. At the full text level, two reviewers (KM and MA) screened studies independently and included studies that provided relevant data. Citations with disagreement went through reconciliation proofs between the two reviewers, and a third coauthor (MK) provided input as needed.

\subsection{Quality Assessment}

We used the strengthening the reporting of observational studies in epidemiology (STROBE) checklist to assess the quality of retrieved studies $(49,50)$. It includes 22 questions that cover different methodological aspects. The highest level of STROBE score was considered 22. If a manuscript obtained lower than $40 \%$ of the highest level of STROBE score, it was considered as low quality, 40-70\% as middle quality, and more than $70 \%$ as high quality. All studies with middle and high quality were included in the main analysis.

\subsection{Data Extraction}

Two of the co-authors (KM and MA) independently extracted data from the included studies using structured sheets in Microsoft Excel@. Afterwards, they discussed and checked the disagreements with the third coauthor (MA) as indicated. We extracted data considering: (1) authors , (2) publication year, (3) country of study, (4) study design, (5) study population type, (6) age characteristics, (7) sample size, (8) gender distribution and, (9) odds ratio (OR) and $95 \% \mathrm{CI}$. 


\subsection{Statistical Analysis}

We used a random-effect model with invers variance weighing method to compute the odds ratios and 95\% CI for tattooing and the risk of hepatitis $C$ infection. The Cochran's Q test and the I2 statistic (51) were used to assess the heterogeneity between studies. We used the Begg's test and Egger's test (53) and visually checked the funnel plot (52) to evaluate the possibility of publication bias. The sensitivity analysis was used to assess the effect of each study on the pooled odds ratio estimation and the pooled odds ratio was calculated after excluding every study. The STATA software version 11.0 was used for all computations (StataCorp, College Station, TX).

\section{Results}

In the first step of search in the electronic databases, we identified 2033 publications relating to risk factors of hepatitis $\mathrm{C}$. In the final step, after removing the duplicates, reviewing the titles, abstracts, and full texts considering the inclusion and exclusion criteria, a total number of 162 studies from 39 countries were selected to enter meta-analysis. Figure 1 shows the details related to step-by-step inclusion and exclusion of the studies. The weighted kappa for eligibility decisions based on the agreement between two reviewers was substantial (Weighted kappa $=0.8, \mathrm{P}<0.001$ ). Characteristics of all the studies included in the systematic review and meta-analysis are shown in Supplement 1. The total sample size of 162 studies (100 cross-sectional, 44 casecontrol, and 18 cohort studies) that reported an association between tattooing and the risk of transmission of hepatitis C was 327,614 subjects.

\subsection{Publication Bias, Pooled Odds Ratio/Relative Risk, and Sub- group Analysis}

There was no evidence of publication bias based on the results from Egger's test $(\mathrm{P}=0.10)$ and Begg's test $(\mathrm{P}=$ 0.17). The results of Chi-square test and I2 statistics showed substantial heterogeneity among the studies that reported tattooing as a risk factor of acquiring HCV infection $(\mathrm{Q}=$ 2364.65 , $\mathrm{P}$ value $<0.001$, and $\mathrm{I} 2=92.6 \%$ ). Consequently, a random effect model was used to analyze data in this study.

When all studies were combined in the meta-analysis, by applying a random effect model, we found a strong significant association between tattooing and transmission risk of hepatitis C infection (pooled OR $=2.79,95 \% \mathrm{CI}: 2.46$ -3.18).

Similarly, in subgroup analyses, we found a strong association between tattooing and risk of hepatitis $\mathrm{C}$ for samples derived from blood donors groups $(\mathrm{OR}=4.09,95 \% \mathrm{CI}$ : 2.80 - 5.98; I $2=83.5 \%)$, followed by military samples $(\mathrm{OR}=$

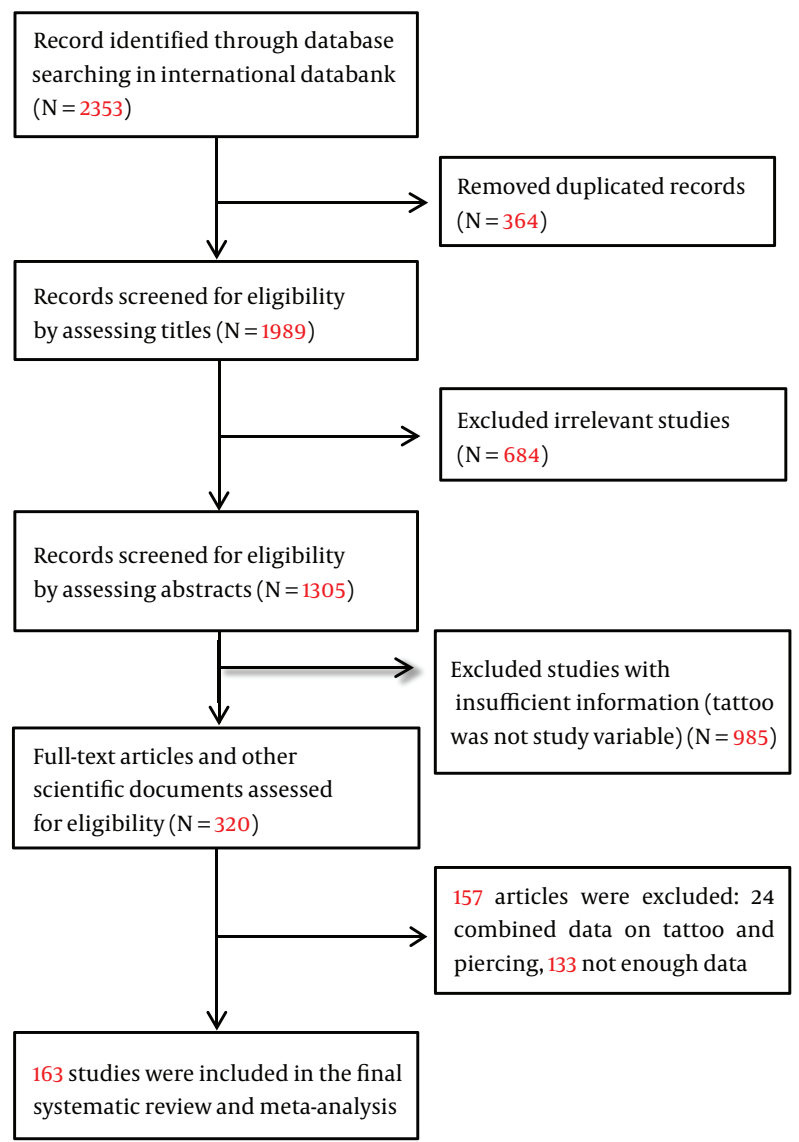

Figure 1. Flow Diagram Showing the Different Phases of Searching for Relevant Publications

3.76, 95\% CI: 2.85 - 4.96; I2 = 0\%), student samples ( $\mathrm{OR}=3.62$, 95\% CI: 0.35 - 37.88; I2 = 95.1\%), non-IDUs (OR=3.56, 95\% CI: 2.31 - 5.50; I2 = 34.2\%), HIV-infected individual samples (OR =3.04, 95\% CI:1.93 - 4.79; I2 = 58.3\%), hospital samples (OR= 2.98, 95\% CI:1.93 - 4.59; I2 = 95\%), prisoners ( OR=2.60, 95\% CI: 2.08 - 3.26; I2 = 90.5\%), community samples ( $\mathrm{OR}=2.37$, 95\% CI:1.82 - 3.09; I2 = 72.6\%), IDUs (OR=2.31, 95\% CI:1.48 - 3.59; I2 $=93 \%)$, homeless samples $(\mathrm{OR}=2.19,95 \% \mathrm{CI}: 1.60-2.99 ; \mathrm{I} 2=$ 13.3\%), drug user samples ( $\mathrm{OR}=1.89,95 \% \mathrm{CI}: 1.26-2.85$; $\mathrm{I} 2=$ $54.9 \%)$, and men who have sex with $\operatorname{men}(\mathrm{OR}=1.69,95 \% \mathrm{CI}$ : 0.78 - 3.67; I $2=64.2 \%$ ) (Figures 2 - 4 and Table 1.

\subsection{Meta Regression Analysis}

Meta-regression was used to investigate the effects of suspected variables such as year of study, sample size, study design, and study population in heterogeneity(Table 2). In univariable meta-regression model, there was a significant association between the study design and pooled odds ratio $(\beta=0.45, \mathrm{P}=0.02)$. In case-control and crosssectional studies, the pooled odds ratio was 0.45 times 


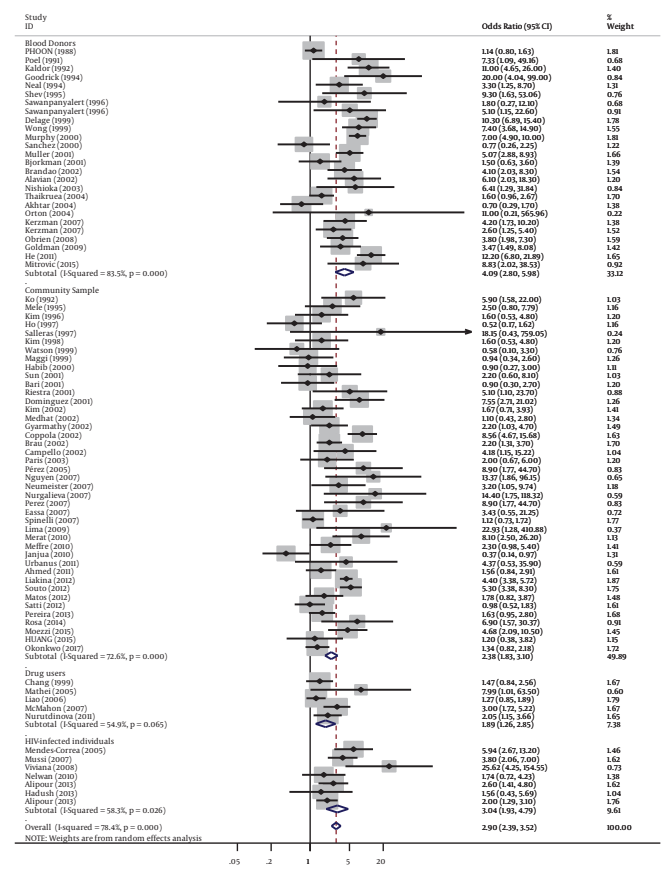

Figure 2. Forest Plot of Tattooing and the Risk of Hepatitis C by Study Population Subgroups

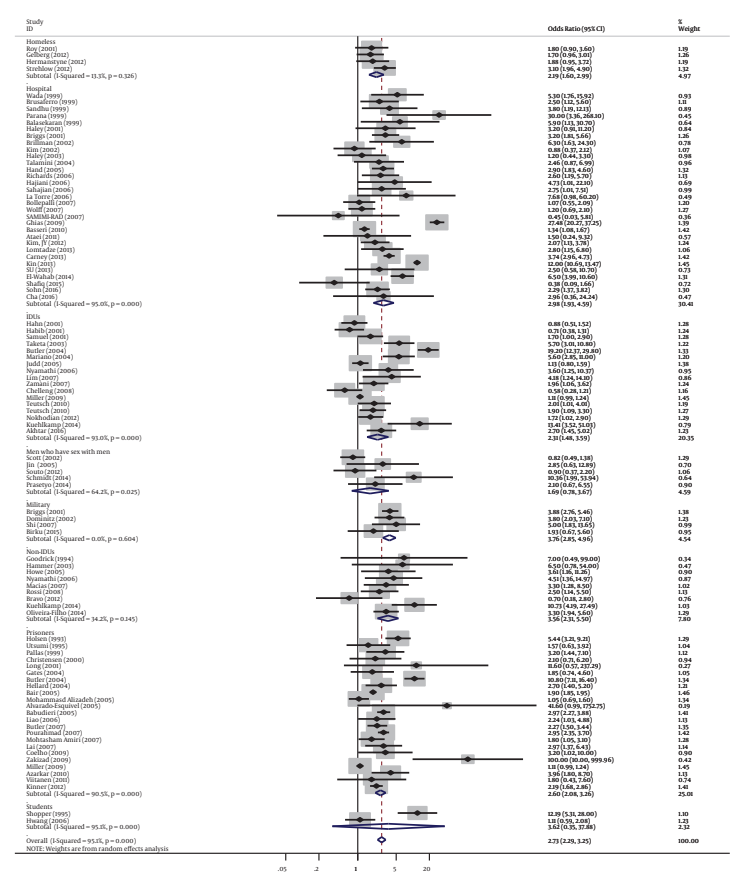

Figure 3. Forest Plot of Tattooing and the Risk of Hepatitis C by Study Population Subgroups (Continue)

higher than that of cohort studies as reference. Neverthe- less, there was no significant association between sample 
Table 1. Results of Subgroup Analysis for Assessing the Association Between Tattooing and Hepatitis C

\begin{tabular}{|c|c|c|c|c|c|}
\hline & Number of OR/RR Included & Subgroups & Pooled OR(Random Effect) & $95 \% \mathrm{CI}$ & I-Squared, $\%^{\mathbf{a}}$ \\
\hline \multicolumn{6}{|c|}{ Stydy design } \\
\hline & 49 & Case-control studies & 3.59 & $2.65-4.87$ & 91.8 \\
\hline & 107 & Cross-sectional studies & 2.66 & $2.32-3.04$ & 83.6 \\
\hline & 20 & Cohort studies & 1.64 & $1.35-2.01$ & 70.8 \\
\hline \multicolumn{6}{|l|}{ Gender } \\
\hline & 24 & Male & 2.13 & $1.64-2.77$ & 69.1 \\
\hline & 3 & Female & 5.17 & $0.89-30$ & 46 \\
\hline & 148 & Total (male and female) & 2.92 & $2.53-3.37$ & 93.6 \\
\hline \multicolumn{6}{|c|}{ Country } \\
\hline \multirow[t]{2}{*}{ Australia } & 3 & Group $1^{b}$ & 4.68 & 1.37-15.99 & 77.7 \\
\hline & 14 & Group2 $^{c}$ & 3.01 & $1.96-4.63$ & 95.7 \\
\hline Argentina & 2 & Group2 & 6.91 & $0.72-66.45$ & 81.5 \\
\hline \multirow[t]{2}{*}{ Brazil } & 7 & Group 1 & 3.55 & $2.05-6.15$ & 74.1 \\
\hline & 8 & Group2 & 4.13 & $1.99-8.59$ & 81 \\
\hline \multirow[t]{2}{*}{ Canada } & 4 & Group 1 & 3.51 & $1.11-11.11$ & 94.5 \\
\hline & 2 & Group2 & 2.25 & $1.15-4.39$ & 14.8 \\
\hline \multirow[t]{2}{*}{ Egypt } & 3 & Group 1 & 1.21 & $0.61-2.40$ & 0 \\
\hline & 1 & Not enough studies (Group2) & $\cdot$ & $\cdot$ & - \\
\hline \multirow[t]{2}{*}{ UK } & 2 & Group 1 & 7.23 & $1.25-41.63$ & 72 \\
\hline & 2 & Group2 & 1.72 & $0.38-7.73$ & 48.15 \\
\hline \multirow[t]{2}{*}{ Iran } & 3 & Group 1 & 5.72 & $3.24-10.10$ & 0 \\
\hline & 12 & Group2 & 2.21 & $1.59-3.8$ & 69 \\
\hline \multirow[t]{2}{*}{ Italy } & 4 & Group 1 & 3.14 & $1.08-9.17$ & 79.2 \\
\hline & 5 & Group2 & 3.20 & $2.47 \cdot 4.16$ & 5.3 \\
\hline \multirow[t]{2}{*}{ Korea } & 3 & Group 1 & 1.63 & $0.92-2.90$ & 0 \\
\hline & 4 & Group2 & 1.86 & $1.23-2.82$ & 19 \\
\hline \multirow[t]{2}{*}{ Pakistan } & 5 & Group 1 & 0.89 & $0.56-1.40$ & 39.2 \\
\hline & 3 & Group2 & 3.36 & $0.38-29.73$ & 97.1 \\
\hline \multirow[t]{2}{*}{ Spain } & 3 & Group 1 & 7.03 & $3.06-16.13$ & 0 \\
\hline & 3 & Group2 & 2.28 & $1.01-5.17$ & 49.2 \\
\hline \multirow[t]{2}{*}{ Taiwan } & 5 & Group 1 & 1.83 & $0.44-7.58$ & 74.2 \\
\hline & 3 & Group2 & 2.01 & $1.29-3.14$ & 56.7 \\
\hline \multirow[t]{2}{*}{ Thailand } & 4 & Group1 & 1.84 & $1.19-2.83$ & 0 \\
\hline & 1 & Not enough studies (Group2) & $\cdot$ & $\cdot$ & $\cdot$ \\
\hline \multirow[t]{2}{*}{ USA } & 9 & Group 1 & 4.02 & $2.14-7.54$ & 81 \\
\hline & 26 & Group2 & 2.60 & $1.77-3.81$ & 97.6 \\
\hline
\end{tabular}

Abbreviation: OR: odds ratio

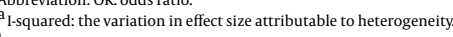

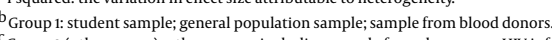

Group 2 (other group): other groups including sample from drug users; HIV infected individuals, homeless individuals, hospital sample, injection drug users (IDUs), men who have sex with men, military forces, non-injection dru users ( Non-IDUs), and prisoners.

size $(\beta=-0.13, \mathrm{P}=0.35)$, year of study $(\beta=-0.007, \mathrm{P}=0.49)$, and study population $(\beta=-0.11, \mathrm{P}=0.38)$ and pooled odds ratio. In multivariable meta-regression model, the study design was significantly associated with pooled effect size; therefore, the case-control and cross-sectional studies had higher odds ratios in comparison with the cohort studies $(\beta=0.43, \mathrm{P}=0.03)$ (Table 2$)$.

\subsection{Sensitivity Analysis}

In sensitivity analysis, to assess the effect of each study on the strength of association between tattooing and hepatitis $\mathrm{C}$, the pooled odds ratio was calculated after excluding each study from the meta-analysis. After excluding every study from the analysis, we found no significant difference between the pre-sensitivity pooled odds ratio ( $\mathrm{OR}=$ 2.79, 95\% CI: 2.46 - 3.18) and post-sensitivity pooled odds ratio. The lower and higher pooled odds ratios in the sensitivity analysis were 2.72 (95\% CI: 2.44 - 3.04) after omitting 
Table 2. Meta-Regression Analysis for Assessing the Effect of Suspected Variables on the Strength of Association

\begin{tabular}{|c|c|c|c|c|c|c|}
\hline \multirow[t]{2}{*}{ Variables } & \multicolumn{3}{|c|}{ Univariable Model } & \multicolumn{3}{|c|}{ Multivariable Model } \\
\hline & $\mathrm{B}$ & SE & PValue $^{a}$ & $\beta$ & SE & PValue $^{a}$ \\
\hline Sample size ${ }^{b}$ & -0.13 & 0.14 & 0.35 & -0.17 & 0.15 & 0.25 \\
\hline Year of study & -0.007 & 0.01 & 0.49 & -0.005 & 0.01 & 0.66 \\
\hline Study design ${ }^{c}$ & 0.45 & 0.19 & 0.02 & 0.43 & 0.20 & 0.03 \\
\hline Study population ${ }^{d}$ & -0.11 & 0.13 & 0.38 & -0.11 & 0.14 & 0.43 \\
\hline
\end{tabular}

${ }^{a}$ P value $<0.05$ considered significant.

${ }^{\mathrm{b}}$ Studies with sample size $>1,000$ versus $<1,000$ as reference.

${ }^{\mathrm{c} C a s e-c o n t r o l ~ a n d ~ c r o s s-s e c t i o n a l ~ s t u d i e s ~ v s . ~ c o h o r t ~ s t u d i e s ~ a s ~ r e f e r e n c e . ~}$

${ }^{\mathrm{d}}$ Sample from drug users; HIV infected individuals, homeless individuals, hospital sample, injection drug users (IDUs), men who have sex with men, military forces, non-injection drug users (Non-IDUs) and prisoners vs. student sample, general population sample and sample from blood donors as reference.

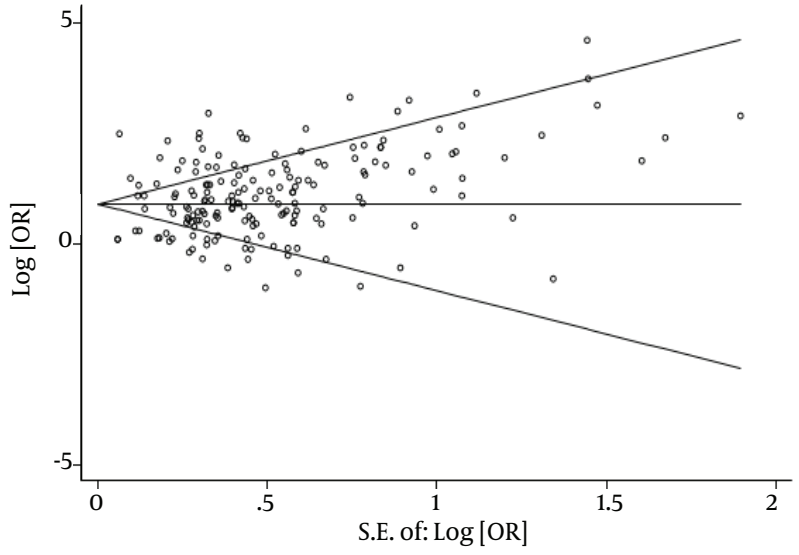

Figure 4. Begg's Funnel Plot for Assessing the Publication Bias

the Kin et al. study (W70 in appendix 1) and 2.83 (95\% CI: 2.48 - 3.22) after omitting the Janjua et al. (w61 in appendix 1) study. We also repeated the sensitivity analysis for each study population subgroups. We found no significant difference between the pre and post sensitivity pooled odds ratios after excluding each study from the subgroup analysis in blood donors subgroup ( $\mathrm{OR}=4.09,95 \% \mathrm{CI}: 2.80-5.98)$, community samples ( $\mathrm{OR}=2.37,95 \%$ CI: $1.83-3.09$ ), drug users (OR $=1.89,95 \%$ CI $1.26-2.84)$, HIV-infected individuals (OR $=3.03,95 \% \mathrm{CI}: 1.92-4.78)$, homeless individuals (OR $=3.75,95 \% \mathrm{CI}: 2.84-4.95)$, hospital samples $(\mathrm{OR}=2.97,95 \%$ CI: 1.92 - 4.58), IDUs ( $\mathrm{OR}=2.30,95 \% \mathrm{CI}: 1.48$ - 3.59), men who have sex with men $(\mathrm{OR}=1.69,95 \% \mathrm{CI}: 0.78-3.67)$, military forces $(\mathrm{OR}=3.75,95 \% \mathrm{CI}: 2.84$ - 4.95), Non-IDUs $(\mathrm{OR}=3.56$, $95 \% \mathrm{CI}: 2.30$ - 5.49), and prisoners ( $\mathrm{OR}=2.60,95 \% \mathrm{CI}: 2.07$ 3.25) (Table 3).

\section{Discussion}

Since the publication of the previous meta-analysis on tattooing and risk of HCV infection (5), 30 case-control, 8 cohort, and 45 cross-sectional studies have been published. The pooled estimation was comparable with that of previous ones for 36 published studies after 2010 together with studies that were not included in previous meta-analysis. Thus, recent studies confirm the evidence indicating that there is a strong association between tattooing and increased risk of hepatitis $C$ infection. The strength of the present review is owing to its multinational nature of the study participants, large number of studies with different designs and considering various study populations and subgroups. Recent studies enriched the current metaanalysis by providing more evidence on tattooing and its strong association with HCV infection. This strong association remained in all subgroups of the study populations such as community samples, blood donors, prisoners, etc. Some supportive evidence exists about the casual association between tattooing and HCV. First, in some studies, a strong association was reported between HCV infection and the number of tattooing experiences as well as the size of body surface covered by tattoos (54-57). Second, our results are consistent with those of other studies that reported the association between tattooing and other infections such as HIV (58), tetanus (58), Methicillin Resistant Staphylococcus Aurous (59), and leprosy (60) as well as with the findings of a systematic review and meta-analysis of Hepatitis B (59). Finally, the strong association remained in all study populations such as community samples and high-risk populations.

Our results showed the strongest association among high-risk populations such as HIV-infected individuals, prisoners, homeless individuals, IDUs, and drug users. These significant associations may be due to some risky behaviors related to tattooing practice such as needle shar- 
Table 3. Results of Sensitivity Analysis to Assess the Effects of Every Study on Pooled Odds Ratio

\begin{tabular}{|c|c|c|c|c|c|c|c|}
\hline \multirow[t]{2}{*}{ Subgroup } & \multicolumn{3}{|c|}{ Pre-Sensitivity Analysis } & \multicolumn{4}{|c|}{ Post-Sensitivity Analysis } \\
\hline & $\begin{array}{l}\text { No. of OR/RR } \\
\text { Included }\end{array}$ & $\begin{array}{c}\text { Pooled OR } \\
\text { (Random Effect) }\end{array}$ & 95\% CI & $\begin{array}{l}\text { Upper and Lower } \\
\text { of }^{\mathrm{EF}} \mathrm{F}^{\mathrm{a}}\end{array}$ & $\begin{array}{c}\text { Pooled OR } \\
\text { (Random Effect) }\end{array}$ & 95\% CI & Excluded Studies \\
\hline \multirow[t]{2}{*}{ Blood donors } & 26 & 4.09 & $2.80-5.98$ & Upper & 4.41 & $3.03-6.41$ & Akhtar \\
\hline & & & & Lower & 3.86 & $2.64-5.66$ & $\mathrm{He}$ \\
\hline \multirow{2}{*}{$\begin{array}{l}\text { Community } \\
\text { sample }\end{array}$} & 43 & 2.37 & $1.82-3.09$ & Upper & 2.48 & $1.92-3.21$ & Janjua \\
\hline & & & & Lower & 2.26 & $1.74-2.93$ & Coppola \\
\hline \multirow[t]{2}{*}{ Drug users } & 5 & 1.89 & $1.26-2.84$ & Upper & 2.20 & $1.43-3.38$ & Liao \\
\hline & & & & Lower & 1.58 & $1.10-2.28$ & McMAhon \\
\hline \multirow{2}{*}{$\begin{array}{l}\text { HIV-infected } \\
\text { individuals }\end{array}$} & 7 & 3.03 & $1.92-4.78$ & Upper & 3.42 & $2.00-5.84$ & Alipour \\
\hline & & & & Lower & 2.67 & $1.69-4.21$ & Mendes-correa \\
\hline \multirow{2}{*}{$\begin{array}{l}\text { Homeless } \\
\text { individuals }\end{array}$} & 4 & 3.75 & $2.84-4.95$ & Upper & 3.94 & $2.95-5.25$ & Birku \\
\hline & & & & Lower & 3.53 & $2.19-5.67$ & Briggs \\
\hline \multirow[t]{2}{*}{ Hospital sample } & 31 & 2.97 & $1.92-4.58$ & Upper & 3.15 & $2.03-4.87$ & Shafiq \\
\hline & & & & Lower & 2.71 & $1.77-4.14$ & Ghias \\
\hline \multirow[t]{2}{*}{ IDUs } & 17 & 2.30 & $1.48-3.59$ & Upper & 2.51 & $1.58-3.97$ & Chelleng \\
\hline & & & & Lower & 1.89 & $1.39-2.58$ & Butler \\
\hline \multirow{2}{*}{$\begin{array}{l}\text { men who have sex } \\
\text { with men }\end{array}$} & 5 & 1.69 & $0.78-3.67$ & Upper & 2.32 & $0.88-6.06$ & Scott \\
\hline & & & & Lower & 1.12 & $0.66-1.89$ & Schmidt \\
\hline \multirow[t]{2}{*}{ Non-IDUs } & 9 & 3.56 & $2.30-5.49$ & Upper & 3.85 & $2.77-5.34$ & Bravo \\
\hline & & & & Lower & 3.04 & $2.16-4.27$ & Kuehlkamp \\
\hline \multirow[t]{2}{*}{ Prisoners } & 23 & 2.60 & $2.07-3.25$ & Upper & 2.78 & $2.19-3.53$ & Miller \\
\hline & & & & Lower & & & \\
\hline \multirow[t]{2}{*}{ Military forces } & 4 & 3.75 & $2.84-4.95$ & Upper & 3.94 & $2.95-5.25$ & Birku \\
\hline & & & & Lower & 3.53 & $2.19-5.67$ & Briggs \\
\hline
\end{tabular}

${ }^{a}$ EF: effect size; the upper and lower limit of effect size (pooled odds ratio) in post-sensitivity analysis after omitting each studies.

ing, reusing tattoo equipment, use of unsterile tattoo equipment, and tattooing in non-professional parlors. The risk of HCV infection due to tattooing may depend on the prevalence of this disease in a target population. Our results indicated that the OR/RR for tattooing among prisoners was higher than that of general populations; however, it was lower than the values of blood donors, military samples, student samples, non-IDUs, and HIV-infected individuals. In previous meta-analyses, the risk of tattooing in prisoners was reported to be lower than the risk of community samples (5). This might be due to a number of reasons including a more detailed subgrouping in our study that separated students and military forces from the general population and differences in the study designs and the sampling methods of the included studies. Another pos- sible reason may be due to that, this study took into consideration new evidence from 2010 publications. Tattooing in the prisoners subgroup is a major concern because of the high prevalence of HCV, HBV, and other blood born infections among this population. In some countries, the prevalence of HCV infection was reported to be 20 times higher among prisoners than the general population (61). Previous studies from Australia, the United States, and Europe indicated that the prevalence of hepatitis $\mathrm{C}$ infection in prisons ranges from $8 \%$ to $57 \%$ (62-65). High risk behaviors as common habits including needle sharing and reusing tattoo needles and equipment were reported $45 \%$ among prisoners $(45,66)$. However, a few prisons worldwide provide sterile needles and syringes for inmates (6769 ), which is a measure unlikely to be adopted by most pris- 
ons and many countries. The results of this study show the need for establishing prevention programs in prisons to provide safer tattooing practices for prisoners. Moreover, similar interventional and educational programs may decrease the risk of other blood-borne infections among the inmates.

According to the WHO program for combating hepatitis B and C and their elimination by 2030 , prevention programs should focus on risk factors and prevent new cases (70). In the general population and other subgroups, some interventions need to be applied to reduce the transmission of hepatitis $\mathrm{C}$ infection among people who tattoo. In developed countries, professional tattooists usually use infection control measures and hygienic precautions. Given that the risks for HCV and other blood borne infections are often similar, it is essential to formulate guidelines to emphasize the importance of appropriate infection control measures and develop educational programs for owners of tattoo parlors and tattoo artists, particularly in developing countries. As majority of tattoo recipients are young adults, it is necessary that the education programs focus on this age group to improve their awareness of tattoorelated risks.

Several strategies can be developed to prevent hepatitis $C$ infection among tattoo recipients. Educational programs for infection control standard precautions should be implemented for tattoo recipients, tattoo artists, and tattoo parlor owners. These standards include proper use of autoclaves, single-use sterile tattoo needles, monitoring sterilization process, and appropriate function of disinfectants. Regular monitoring and supervision by health care centers may improve adherence to the standards in tattoo parlors. Records of tattoo recipients should be kept by tattoo parlors and they should report any side effects relating to tattooing to local health centers (71). Finally, it is suggested that clinicians consider screening for hepatitis $\mathrm{C}$ and other blood-born viral infections among those who have a history of receiving tattoos as a high-risk population. A limitation of this study is that, because of the observational nature of the studies included in the review, recall bias may affect the results due to lower validity of data gathered in these studies. In addition, information on the history of tattooing may not reflect the current population risk of hepatitis $C$ infection. Further studies are needed to determine the current status of tattooing and risk of hepatitis $C$ in order to gain a comprehensive understanding of the association between tattooing and hepatitis $\mathrm{C}$ infection.

\section{Supplementary Material}

Supplementary material(s) is available here.

\section{Acknowledgments}

This study was extracted from a research project No. 1429-94, approved by Baqiyatallah University of Medical Sciences. Hereby, we express our deepest gratitude to Baqiyatallah research center for gastroenterology and liver diseases (BRCGL) for their financial support.

\section{Footnotes}

Authors' Contribution: All authors: data collection; Mahmoud Khodadoust: statistical analysis; Mahmoud Khodadoust and Seyed Moayed Alavian: study design; Mahmoud Khodadoust and Khadije Maajani: quality assessment; all authors: final revision and grammar editing.

Funding/Support: Baqiyatallah research center for gastroenterology and liver diseases (BRCGL) financially supported the current study by grant No 1429-94.

Conflict of Interests: No conflict of interest is reported by the authors.

\section{References}

1. Grumet GW. Psychodynamic implications of tattoos. Am JOrthopsychiatry. 1983;53(3):482-92. [PubMed: 6349373].

2. Thomson W, McDonald JC. Self-tattooing by schoolchildren. Lancet. 1983;2(8361):1243-4. [PubMed: 6139581].

3. Laumann AE, Derick AJ. Tattoos and body piercings in the United States: a national data set. J Am Acad Dermatol. 2006;55(3):413-21. doi: 10.1016/j.jaad.2006.03.026. [PubMed: 16908345].

4. Deschesnes M, Demers S, Fines P. Prevalence and characteristics of body piercing and tattooing among high school students. Can JPublic Health. 2006;97(4):325-9. [PubMed:16967755].

5. Jafari S, Copes R, Baharlou S, Etminan M, Buxton J. Tattooing and the risk of transmission of hepatitis C: a systematic review and meta-analysis. Int J Infect Dis. 2010;14(11):e928-40. doi: 10.1016/j.ijid.2010.03.019. [PubMed: 20678951].

6. Meyer RA, Gordon SC. Epidemiology of hepatitis C virus infection in a suburban Detroit community. Am J Gastroenterol. 1991;86(9):1224-6. [PubMed: 1652886].

7. Esteban JI, Lopez-Talavera JC, Genesca J, Madoz P, Viladomiu L, Muniz E, et al. High rate of infectivity and liver disease in blood donors with antibodies to hepatitis C virus. Ann Intern Med. 1991;115(6):443-9. [PubMed: 1651674].

8. Iwamura K, Pronai L, Nishioka K, Watanabe J. [Incidence of hepatitis $\mathrm{C}$ in chronic liver diseases following tattooing]. Orv Hetil. 1992;133(15):923-5. [PubMed:1574328].

9. Ko YC, Ho MS, Chiang TA, Chang SJ, Chang PY. Tattooing as a risk of hepatitis C virus infection. J Med Virol. 1992;38(4):288-91. [PubMed: 1282147].

10. Memon MI, Memon MA. Hepatitis C: an epidemiological review.JViral Hepat. 2002;9(2):84-100. [PubMed: 11876790].

11. Karmochkine M, Carrat F, Dos Santos O, Cacoub P, Raguin G. A casecontrol study of risk factors for hepatitis $\mathrm{C}$ infection in patients with unexplained routes of infection. J Viral Hepat. 2006;13(11):775-82. doi: 10.1111/j.1365-2893.2006.00742.x. [PubMed:17052278]. 
12. Delarocque-Astagneau E, Pillonel J, De Valk H, Perra A, Laperche S, Desenclos JC. An incident case-control study of modes of hepatitis C virus transmission in France. Ann Epidemiol. 2007;17(10):755-62. doi: 10.1016/j.annepidem.2007.05.007. [PubMed: 17728145].

13. Shepard CW, Finelli L, Alter MJ. Global epidemiology of hepatitis C virus infection. Lancet Infect Dis. 2005;5(9):558-67. doi: 10.1016/S14733099(05)70216-4. [PubMed: 16122679].

14. Birku T, Gelaw B, Moges F, Assefa A. Prevalence of hepatitis B and $C$ viruses infection among military personnel at Bahir Dar Armed Forces General Hospital, Ethiopia. BMC Res Notes. 2015;8:737. doi: 10.1186/s13104-015-1719-2. [PubMed: 26625733].

15. Nguyen LH, Nguyen MH. Systematic review: Asian patients with chronic hepatitis C infection. Aliment Pharmacol Ther. 2013;37(10):92136. doi: 10.1111/apt.12300. [PubMed: 23557103].

16. Seeff LB. Natural history of chronic hepatitis C. Hepatology. 2002;36(5 Suppl 1):S35-46. doi: 10.1053/jhep.2002.36806. [PubMed: 12407575].

17. Lee SS, Jeong SH, Jang ES, Kim YS, Lee YJ, Jung EU, et al. Prospective cohort study on the outcomes of hepatitis $C$ virus-related cirrhosis in South Korea. J Gastroenterol Hepatol. 2015;30(8):1281-7. doi: 10.1111/jgh.12950. [PubMed: 25778783].

18. Bruix J, Barrera JM, Calvet X, Ercilla G, Costa J, Sanchez-Tapias JM, et al. Prevalence of antibodies to hepatitis $C$ virus in Spanish patients with hepatocellular carcinoma and hepatic cirrhosis. Lancet. 1989;2(8670):1004-6. [PubMed: 2572739].

19. Poynard T, Bedossa P, Opolon P. Natural history of liver fibrosis progression in patients with chronic hepatitis C. The OBSVIRC, METAVIR, CLINIVIR, and DOSVIRC groups. Lancet. 1997;349(9055):82532. [PubMed: 9121257].

20. Alberti A, Chemello L, Benvegnu L. Natural history of hepatitis C. J Hepatol. 1999;31 Suppl 1:17-24. [PubMed: 10622555].

21. Alter MJ, Margolis HS. Recommendations for prevention and control of hepatitis C virus (HCV) infection and HCV-related chronic disease. ;1998.

22. Alter MJ, Kruszon-Moran D, Nainan OV, McQuillan GM, Gao F, Moyer LA, et al. The prevalence of hepatitis $C$ virus infection in the United States, 1988 through 1994. N Engl J Med. 1999;341(8):556-62. doi: 10.1056/NEJM199908193410802. [PubMed: 10451460].

23. Sun CA, Chen HC, Lu CF, You SL, Mau YC, Ho MS, et al. Transmission of hepatitis $C$ virus in Taiwan: prevalence and risk factors based on a nationwide survey.J Med Virol. 1999;59(3):290-6. [PubMed:10502258].

24. Shin HR. Epidemiology of hepatitis $C$ virus in Korea. Intervirology. 2006;49(1-2):18-22. doi: 10.1159/000087258. [PubMed: 16166784].

25. Kim YS, Ahn YO, Kim DW. A case-control study on the risk factors of hepatitis C virus infection among Koreans. J Korean Med Sci. 1996;11(1):38-43. doi: 10.3346/jkms.1996.11.1.38. [PubMed: 8703369].

26. Hellard ME, Hocking JS, Crofts N. The prevalence and the risk behaviours associated with the transmission of hepatitis $\mathrm{C}$ virus in Australian correctional facilities. Epidemiol Infect. 2004;132(3):409-15. [PubMed: 15188710].

27. Davis AR. Tattoo parlours and hepatitis $C$ virus infection. Med J Aust. 1995;163(10):556-7. [PubMed: 8538530].

28. Simonian PT, Gilbert M, Trumble TE. Incidence of hepatitis C in patients requiring orthopaedic surgery. J Bone Joint Surg Br. 1995;77(6):971-4. [PubMed: 7593117].

29. Brind AM, Watson JP, James OF, Bassendine MF. Hepatitis C virus infection in the elderly. QJM. 1996;89(4):291-6. [PubMed: 8733516].

30. Sun DX, Zhang FG, Geng YQ, Xi DS. Hepatitis C transmission by cosmetic tattooing in women. Lancet. 1996;347(9000):541. [PubMed: 8596286].

31. Thompson SC, Hernberger F, Wale E, Crofts N. Hepatitis C transmission through tattooing: a case report. Aust $N$ Z J Public Health. 1996;20(3):317-8. [PubMed: 8768424].

32. Mele A, Corona R, Tosti ME, Palumbo F, Moiraghi A, Novaco F, et al. Beauty treatments and risk of parenterally transmitted hepatitis: results from the hepatitis surveillance system in Italy. Scand J Infect Dis. 1995;27(5):441-4. [PubMed: 8588131].
33. Kaldor JM, Archer GT, Buring ML, Ismay SL, Kenrick KG, Lien AS, et al. Risk factors for hepatitis $\mathrm{C}$ virus infection in blood donors: a casecontrol study. Med J Aust. 1992;157(4):227-30. [PubMed: 1279364].

34. Parana R, Vitvitski L, Andrade Z, Trepo C, Cotrim H, Bertillon P, et al. Acute sporadic non-A, non-B hepatitis in Northeastern Brazil: etiology and natural history. Hepatology. 1999;30(1):289-93. doi: 10.1002/hep.510300143. [PubMed: 10385669].

35. Kuberski T, LeGonidec G, Gust ID, Dimitrakakis M, Cantaloube D, Zimmet P. Hepatitis B virus infections in Melanesians and Polynesians in New Caledonia. Am J Epidemiol. 1981;114(3):355-61. [PubMed: 7304571].

36. Tibbs CJ. Hepatitis B, tropical ulcers, and immunisation strategy in Kiribati. Br Med J (Clin Res Ed). 1987;294(6571):537-40. [PubMed: 3103763].

37. Phoon WO, Fong NP, Lee J. History of blood transfusion, tattooing, acupuncture and risk of hepatitis B surface antigenaemia among Chinese men in Singapore. Am J Public Health. 1988;78(8):958-60. [PubMed: 3389434].

38. Dufour A, Alary M, Poulin C, Allard F, Noel L, Trottier G, et al. Prevalence and risk behaviours for HIV infection among inmates of a provincial prison in Quebec City. AIDS. 1996;10(9):1009-15. [PubMed: 8853735].

39. Conry-Cantilena C, VanRaden M, Gibble J, Melpolder J, Shakil AO, Viladomiu L, et al. Routes of infection, viremia, and liver disease in blood donors found to have hepatitis $\mathrm{C}$ virus infection. $N$ Engl J Med. 1996;334(26):1691-6. doi: 10.1056/NEJM199606273342602. [PubMed: 8637513].

40. Garner JJ, Gaughwin M, Dodding J, Wilson K. Prevalence of hepatitis C infection in pregnant women in South Australia. Med J Aust. 1997;167(9):470-2. [PubMed: 9397060].

41. Murphy EL, Bryzman SM, Glynn SA, Ameti DI, Thomson RA, Williams $A E$, et al. Risk factors for hepatitis $C$ virus infection in United States blood donors. NHLBI Retrovirus Epidemiology Donor Study (REDS). Hepatology. 2000;31(3):756-62. doi: 10.1002/hep.510310329. [PubMed: 10706569].

42. Tohme RA, Holmberg SD. Transmission of hepatitis $C$ virus infection through tattooing and piercing: a critical review. Clin Infect Dis. 2012;54(8):1167-78. doi:10.1093/cid/cir991. [PubMed: 22291098].

43. Carney K, Dhalla S, Aytaman A, Tenner CT, Francois F. Association of tattooing and hepatitis $\mathrm{C}$ virus infection: a multicenter casecontrol study. Hepatology. 2013;57(6):2117-23. doi: 10.1002/hep.26245. [PubMed: 23315899].

44. Weild AR, Gill ON, Bennett D, Livingstone SJ, Parry JV, Curran L. Prevalence of HIV, hepatitis B, and hepatitis C antibodies in prisoners in England and Wales: a national survey. Commun Dis Public Health. 2000;3(2):121-6. [PubMed:10902255].

45. Crofts N, Stewart T, Hearne P, Ping XY, Breshkin AM, Locarnini SA. Spread of bloodborne viruses among Australian prison entrants. BMJ. 1995;310(6975):285-8. [PubMed: 7866168].

46. Ruiz JD, Molitor F, Sun RK, Mikanda J, Facer M, Colford JJ, et al. Prevalence and correlates of hepatitis $C$ virus infection among inmates entering the California correctional system. West JMed. 1999;170(3):15660. [PubMed: 10214102].

47. Kondro W. Prison tattoo program wasn't given enough time. CMAJ. 2007;176(3):307-8. doi:10.1503/cmaj.070017. [PubMed: 17215479].

48. Poulin C, Alary M, Lambert G, Godin G, Landry S, Gagnon H, et al. Prevalence of HIV and hepatitis $\mathrm{C}$ virus infections among inmates of Quebec provincial prisons. CMAJ. 2007;177(3):252-6. doi: 10.1503/cmaj.060760. [PubMed: 17664448].

49. von Elm E, Altman DG, Egger M, Pocock SJ, Gotzsche PC, Vandenbroucke JP, et al. The Strengthening the Reporting of Observational Studies in Epidemiology (STROBE) statement: guidelines for reporting observational studies. Prev Med. 2007;45(4):247-51. doi: 10.1016/j.ypmed.2007.08.012. [PubMed:17950122].

50. Akbari M, Moosazadeh M, Tabrizi R, Khatibi SR, Khodadost M, Heydari ST, et al. Estimation of iron deficiency anemia in Iranian children and adolescents: a systematic review and meta-analysis. Hematology. 
2017;22(4):231-9.

51. Higgins JP, Thompson SG. Quantifying heterogeneity in a metaanalysis. Stat Med. 2002;21(11):1539-58. doi:10.1002/sim.1186. [PubMed: 12111919].

52. Light RJ, Pillemer DB. Summing Up: The Science of Reviewing Research. Massachusetts: Harvard University; 1984.

53. Egger M, Davey Smith G, Schneider M, Minder C. Bias in meta-analysis detected by a simple, graphical test. BMJ. 1997;315(7109):629-34. [PubMed: 9310563].

54. Roy E, Haley N, Leclerc P, Boivin JF, Cedras L, Vincelette J. Risk factors for hepatitis $\mathrm{C}$ virus infection among street youths. CMAJ. 2001;165(5):557-60. [PubMed: 11563207].

55. Kim YS, Ahn YO, Lee HS. Risk factors for hepatitis $C$ virus infection among Koreans according to the hepatitis $\mathrm{C}$ virus genotype. J Korean Med Sci. 2002;17(2):187-92. doi: 10.3346/jkms.2002.17.2.187. [PubMed: 11961301].

56. Haley RW, Fischer RP. Commercial tattooing as a potentially important source of hepatitis C infection. Clinical epidemiology of 626 consecutive patients unaware of their hepatitis $C$ serologic status. Medicine (Baltimore). 2001;80(2):134-51. [PubMed: 11307589]

57. Post JJ, Dolan KA, Whybin LR, Carter IW, Haber PS, Lloyd AR. Acute hepatitis $C$ virus infection in an Australian prison inmate: tattooing as a possible transmission route. Med J Aust. 2001;174(4):183-4. [PubMed: 11270759].

58. Nishioka S, Gyorkos TW. Tattoos as risk factors for transfusiontransmitted diseases. Int J Infect Dis. 2001;5(1):27-34. [PubMed: 11285156].

59. Centers for Disease C. Methicillin-resistant Staphylococcus aureus skin infections among tattoo recipients-Ohio, Kentucky, and Vermont, 2004-2005. MMWR Morb Mortal Wkly Rep. 2006;55(24):677-9. [PubMed: 16791134].

60. Ghorpade A. Inoculation (tattoo) leprosy: a report of 31 cases. J Eur Acad Dermatol Venereol. 2002;16(5):494-9. [PubMed: 12428846].

61. Calzavara L, Ramuscak N, Burchell AN, Swantee C, Myers T, Ford P, et al. Prevalence of HIV and hepatitis $C$ virus infections among inmates of Ontario remand facilities. CMAJ. 2007;177(3):257-61. doi: 10.1503/cmaj.060416. [PubMed: 17664449].

62. Backmund M, Meyer K, Wachtler M, Eichenlaub D. Hepatitis C virus infection in injection drug users in Bavaria: risk factors for seropositivity. Eur J Epidemiol. 2003;18(6):563-8. [PubMed: 12908723].

63. Baillargeon J, Wu H, Kelley MJ, Grady J, Linthicum L, Dunn K. Hepatitis C seroprevalence among newly incarcerated inmates in the Texas correctional system. Public Health. 2003;117(1):43-8. [PubMed: 12802904].

64. Burek V, Horvat J, Butorac K, Mikulic R. Viral hepatitis B, C and HIV infection in Croatian prisons. Epidemiol Infect. 2010;138(11):1610-20. doi: 10.1017/S0950268810000476. [PubMed: 20202285].

65. Robaeys G, Arain A, Stöver H. Emerging Issues in Prison Health Springer; 2017. pp.169-81.Hepatitis $C$ viral infection in prisons.

66. Treloar C, McCredie L, Lloyd AR. The Prison Economy of Needles and Syringes: What Opportunities Exist for Blood Borne Virus Risk Reduction When Prices Are so High? PLoS One. 2016;11(9):e0162399. doi: 10.1371/journal.pone.0162399. [PubMed: 27611849].

67. Kamynina E, Stover PJ. The Roles of SUMO in Metabolic Regulation. Adv Exp Med Biol. 2017;963:143-68. doi: 10.1007/978-3-319-50044-7_9. [PubMed: 28197911].

68. Brinkley-Rubinstein L, Cloud DH, Davis C, Zaller N, Delany-Brumsey A, Pope $L$, et al. Addressing excess risk of overdose among recently incarcerated people in the USA: harm reduction interventions in correctional settings. Int J Prison Health. 2017;13(1):25-31. doi: 10.1108/IJPH08-2016-0039. [PubMed: 28299971].

69. Stöver H, Hariga F. Prison-based needle and syringe programmes (PNSP) - Still highly controversial after all these years. Drugs Educ Prevent Policy. 2016;23(2):103-12. doi: 10.3109/09687637.2016.1148117.

70. WHO . Combating hepatitis B and C to reach elimination by 2030 : advocacy brief 2016. Available from: http://www.who.int/iris/handle/ $10665 / 206453$.

71. Jafari S, Buxton JA, Afshar K, Copes R, Baharlou S. Tattooing and risk of hepatitis B: a systematic review and meta-analysis. Can J Public Health. 2012;103(3):207-12. [PubMed: 22905640]. 